\title{
The Dynamics of Japanese Firm Growth in U.S. Industries: The Penrose Effect
}

\author{
Danchi Tan \\ Assistant Professor, National Chengchi University
}

\author{
Joseph T. Mahoney \\ University of Illinois at Urbana-Champaign
}

\begin{abstract}
This research paper explores the conditions under which a firm is more/less likely to incur the Penrose Effect when expanding in a foreign market. We posit that multinational firms that can accelerate the development of new managerial resources in their foreign operations have greater organizational capabilities to adjust their managerial resources timely in the process of expansion, and thus will be less vulnerable to a severe managerial constraint on the rate of growth. In contrast, factors that impede the development of new managerial resources in foreign operations will prevent multinational firms from growing fast in consecutive time periods. Based on a longitudinal sample of Japanese manufacturing entries in the United States, our empirical results indicate that Japanese firms were able to achieve growth in consecutive time periods when these firms sent more expatriates to the foreign operations at the time of entry, and when these Japanese firms had greater home experience prior to their entry into the U.S. market. On the other hand, Japanese firms were found to be less able to achieve growth in consecutive time periods when a high level of uncertainty characterized the U.S. markets that these Japanese firms entered.
\end{abstract}

Published: 2005

URL: http://www.business.uiuc.edu/Working Papers/papers/05-0121.pdf 
The Dynamics of Japanese Firm Growth in U.S. Industries: The Penrose Effect

\author{
Danchi Tan \\ Assistant Professor \\ Department of International Trade \\ National Chengchi University \\ 64, Chih-nan Rd.,Sec. 2 \\ Wenshan, Taipei 11623 \\ Taiwan \\ Tel: +886 2 2939-3091 ext 81139 \\ Fax: +8862 2938-7699 \\ E-mail: dctan@nccu.edu.tw \\ and \\ Joseph T. Mahoney \\ Professor of Strategy \\ Department of Business Administration \\ College of Business \\ University of Illinois at Urbana-Champaign \\ 350 Wohlers Hall \\ 1206 South Sixth Street \\ Champaign, IL 61820 \\ (217) 244-8257 (telephone) \\ (217) 244- 7969 (fax) \\ E-mail: josephm@express.cites.uiuc.edu
}




\title{
The Dynamics of Japanese Firm Growth in U.S. Industries: The Penrose Effect
}

\begin{abstract}
This research paper explores the conditions under which a firm is more/less likely to incur the Penrose Effect when expanding in a foreign market. We posit that multinational firms that can accelerate the development of new managerial resources in their foreign operations have greater organizational capabilities to adjust their managerial resources timely in the process of expansion, and thus will be less vulnerable to a severe managerial constraint on the rate of growth. In contrast, factors that impede the development of new managerial resources in foreign operations will prevent multinational firms from growing fast in consecutive time periods. Based on a longitudinal sample of Japanese manufacturing entries in the United States, our empirical results indicate that Japanese firms were able to achieve growth in consecutive time periods when these firms sent more expatriates to the foreign operations at the time of entry, and when these Japanese firms had greater home experience prior to their entry into the U.S. market. On the other hand, Japanese firms were found to be less able to achieve growth in consecutive time periods when a high level of uncertainty characterized the U.S. markets that these Japanese firms entered.
\end{abstract}


In the seminal research book of resource-based theory, The Theory of the Growth of the Firm, Penrose (1959) submits that a lack of managerial resources is typically the major obstacle that impedes the growth rate of a firm. Growth does not take place automatically, but must be planned strategically and implemented effectively by managers who have firm-specific experiences internal to the firm (Penrose, 1959; Kor and Mahoney, 2000; Pitelis, 2002; Mahoney, 2005). Because such managers must be developed within the firm and cannot be hired from the outside, the capacities of internally experienced managers set a limit to the expansion projects that a firm can undertake in any period of time (Rubin, 1973; Slater, 1980). Accordingly, a firm that expands rapidly in one time period is likely to incur managerial problems and consequently the firm's growth may stagnate in the subsequent time period. The logic here is essentially that the firm is not likely to be able to adjust timely its managerial resources to the desired level to deal with the increased organizational complexity that is typically associated with a rapid rate of firm-level expansion, leading to time compression diseconomies (Dierickx and Cool, 1989) and dynamic adjustment costs (Lucas, 1967; Treadway, 1970; Mortensen, 1973; Slater, 1980).

The economic impact of managerial constraints on the rate of growth of the firm is cited as the Penrose Effect in the research literature (Marris, 1963; Shen, 1970; Hay and Morris, 1991). A limited number of research studies have empirically examined whether the Penrose Effect exists (Shen, 1970, Gander, 1991; Thompson, 1994; Shane, 1996; Orser, Hogarth-Scott and Riding, 2000; Tan, 2003). In general, these research studies provide supportive, but not robust empirical evidence for the Penrose Effect, and the strength of the Penrose Effect varies with the types of expansion, and the firms considered in the samples (Tan and Mahoney, 2005).

While these research studies improve our understanding of the economic impact of managerial constraints on the rate of the growth of the firm, at least two research issues require 
further consideration. First, previous empirical studies mainly focus on whether the Penrose Effect exists. Just as firms are endowed with different technological capabilities, firms may be endowed with different managerial capabilities and thus may encounter managerial constraints differently. However, researchers have under-emphasized the possibility of firms incurring differential managerial constraints and have under-explored the conditions under which the Penrose Effect is more likely to prevail. Second, although international expansion is an important strategic option enabling a firm to achieve growth, empirical studies that examine the Penrose Effect are rare (Tan, 2003; Tan and Mahoney, 2005).

The current empirical paper attempts to improve such an understanding by exploring the conditions under which the Penrose Effect is more likely to prevail from the perspective of the supply of managerial resources and by examining these conditions empirically in an international business context. To our knowledge, only three empirical studies have investigated the conditions under which firms encounter more substantial managerial constraints. All have centered on the demand for managerial resources. Thompson (1994) and Shane (1996) show that U.S. firms following a franchise strategy grew faster than those that expanded via establishing hierarchical outlets because the latter are subject to a greater managerial constraint. The third empirical paper (Tan and Mahoney, 2005) found that the higher the need for coordinating cross-border intra-firm units, the greater the Penrose Effect, for Japanese firms entering the U.S. market. In general, these empirical studies found that the Penrose Effect is highly likely to be more substantial for firms that engage in business activities that are more demanding of managerial services from internal experienced managers.

The current research paper complements the previous empirical studies by focusing on the supply of managerial resources. Specifically, we consider the possibility that multinational 
firms may have different organizational capabilities for developing new managerial resources (Nelson and Winter, 1982; Teece, Pisano and Shuen, 1997; Verbeke, 2003). We posit that multinational firms are less likely to be impeded by the Penrose Effect when these firms have greater organizational capabilities in developing new managerial resources abroad in a timely fashion (Chang, 1995). We explore several conditions under which firms are more likely to do so, and we test these conditions empirically.

The current paper is organized as follows. The next section summarizes Penrose's (1959) theory of the growth of the firm and develops several hypotheses concerning the conditions under which firms are likely to face greater managerial constraints on the rate of growth. We then describe the data and measures for empirical tests of the hypotheses and report the empirical results. The final section discusses the empirical results and provides conclusions.

\section{Penrose's Theory of the Growth of the Firm}

What influences the rate at which a firm grows? According to Penrose (1959), managers that have experience internal to the firm can influence the growth rate of the firm in at least three ways. First, the managerial services from internally experienced managers are a required input for the operation of a firm and the capacities of the existing management team set a limit to the rate at which a firm can grow in any given period of time. Penrose suggests that the very nature of a firm is an administrative organization, which requires that managers with experience internal to the firm "at least know and approve, even if they do not in detail control all aspects of, the plans and operations of the firm" (1959: 45). In particular, internally experienced managers typically work together as a team. Individuals new to the firm cannot provide services that allow the managerial team to function as a team, and to be useful for the firm these new personnel need to gain experience from working together with existing managers within the firm. In addition, the 
process of decision-making within the firm is too complex to be codified as a management "blueprint" for implementation by these newly recruited managers. Because internally experienced managers can only be developed within the firm over time, firms are faced with an inelastic supply of managerial resources, at least in the short run. Consequently, the capacities of internally experienced managers set a limit to the scope and complexity of operations that a firm can plan and manage in any given period of time.

Second, the managerial capacities of management not only limit, but also provide an inducement to firm-level growth, because these managerial capacities within a firm can grow over time. Specifically, strategic planning and implementation of different expansion projects expose the existing managers to various stimuli that allow the managers to develop their managerial repertoires (Huber, 1991; Mahoney, 1995). As a result, existing managers can expand their skills through learning on the job. A firm can also gain access to new managerial resources when its newly recruited managers gain firm-specific experience by working with existing managers. In addition, while strategic planning and implementing an expansion project absorbs the time and attention from internally experienced managers, as the firm encounters recurrent challenges in the particular environment, its responses to these challenges can evolve into a set of routines (Nelson and Winter, 1982) that economize the capacities of existing managers. Therefore, managerial resources can be released from completed projects and become available for further expansion.

The increase in managerial capacities would not facilitate the growth of the firm if the firm would not attempt to utilize them. For Penrose (1959), firms that pursue long-term profits will tend to search for ways of using resources more profitably. Because at least a part of the (excess) managerial resources are firm specific in nature, these resources are more valuable 
economically within the firm than outside the firm in strategic factor markets (Barney, 1986). As a result, the growing managerial resources, once not fully used in the current operations of a firm, provide an economic incentive to further expansion.

Finally, the capacities of existing managers also influence the development of new managerial resources. To be able to provide managerial services that are economically valuable to the firm, newly recruited personals need to learn "the best way of doing things in the particular set of circumstances in which they are working" (Penrose, 1959: 52). Existing managers mentor newly recruited managers in the sense that the existing managers provide to the new recruits the tacit knowledge (Polanyi, 1962; Subramaniam and Venkatraman, 2001) of the ways things work. Because the process of mentoring involves face-to-face interactions between existing managers and new recruits, the capacities of existing managers limit the rate at which new managerial resources can be developed. In addition, newly recruited managers gain team-level experience though learning on the job. Hence, the plans put into effect by existing managers restrict the opportunities of newly hired personnel gaining the requisite experience (Penrose, 1959).

Therefore, the capacities of internally experienced managers have important influences on the growth rate of a firm. Firms that expand faster than their existing managers can effectively plan and implement are likely to incur managerial difficulties that result in inefficiencies. In addition, these experienced managers in fast-growing firms will have little time for mentoring newly recruited managers. As a result, such firms will develop fewer new managerial resources, further hampering their subsequent expansion. The impact of managerial constraints on firms is cited as the Penrose Effect in the research literature (Marris, 1964, Shen, 1970), and this concept indicates that firms that grow fast in one time period are likely to stagnate in the successive time period. 
While the capacities of internally experienced managers have an important influence on the rate of growth of firms, the extent to which firms are subject to managerial constraints may vary, because firms may have different organizational capabilities for developing new managerial resources during the process of expansion. In the next section, we consider, specifically, international expansion and the Penrose Effect.

\section{International Expansion and the Penrose Effect}

International expansion, like other forms of expansion, requires managerial services of internally experienced managers of the headquarters. These headquarters' managers need to spend time in planning and in implementing expansion projects. For example, headquarters' managers may be in charge of choosing the locations, entry modes, methods of finance, and so forth. Once the firms have entered into the chosen markets, these managers need to collect and evaluate the information from overseas subunits and provide proper coordination and control to them (Edstrom and Galbraith, 1977; Ouchi, 1979; Eisenhardt, 1985; Hennart, 1991; O’Donnell, 2000). In addition, the headquarters' managers may also transfer knowledge and/or corporate managerial practices to the overseas subunits (Beechler and Yang, 1994).

Multinational firms may incur the Penrose Effect to different extents because they can differ in the speed in developing new managerial resources in the process of international expansion. As discussed earlier, developing new managerial resources requires the services from internally experienced managers of the headquarters. While multinational firms may be able to recruit local personnel for managing daily operations of their overseas subunits, these newly recruited local personnel need to develop team experiences if they are to be effective in making decisions within the subsidiary. The headquarters' managers influence the learning of newly recruited personnel by planning and explaining the tasks from which new personnel can gain the 
requisite experience. In addition, to make sure that the overseas subunits are conforming to the expectations of the headquarters and can contribute to the multinational firm as a whole, the headquarters managers may need to spend time and efforts in assimilating the newly recruited local managers into the corporate culture and in transferring the corporate managerial practices to the overseas subunits. In other words, the headquarters managers need to oversee the development of local personnel's capability in achieving coordination within the multinational firm.

Expatriates are a major mechanism by which multinational firms influence the development of local personnel. Expatriates typically have been worked and socialized within the multinational headquarters for a period of time so that they have accumulated experience internal to the multinational headquarters by the time they receive the international assignment. Through these experiences, expatriates gain an understanding of the multinational headquarters' corporate policies and develop relationships with people in the headquarters (Kuemmerle, 1997). Therefore, the use of expatriates in the establishment stage of a foreign operation allows the multinational headquarters to institute the corporate culture and management policies in the operation, and to train newly recruited local personnel so that these local personnel can understand and conform to the headquarters' expectations (Edstrom and Galbraith, 1977).

In sum, at the initial stage of a foreign operation, expatriates play an important role in shaping the environment in which newly-recruited local personnel gain experiences and in assimilating these experiences. In other words, expatriates influence the development of newly recruited local personnel in the foreign operation. As discussed earlier, implementation of expansion projects can distract managerial attention from developing new managerial resources. In multinational firms that send a greater number of expatriates to a foreign operation at the time 
of establishment, expatriates are more likely to be able to provide more time and attention to nurture newly recruited local personnel. Thus, such firms may incur a less serious managerial constraint when expanding in the foreign market. Therefore, we expect that:

\section{H1: Multinational firms that send a greater number of expatriates to their overseas operations upon entry into a foreign market are more likely to achieve high growth rates in successive time periods in the market.}

A multinational firm may be able to accelerate the development of local personnel if the procedures in the firm have evolved as a complete set of routines (Cyert and March, 1963). Routines summarize the ways of doing things in the particular working environment within the firm (Levitt and March, 1988). The use of routines economizes managerial attention because routines suppress deliberate (managerial) choices (March and Simon, 1958) and reduce the need in searching for optimal solutions (Nelson and Winter, 1982). Routines also reduce potential intra-organizational conflicts and thus facilitate coordination with various members in organizations (Cyert and March, 1963). Routines also economize the time of managers in transferring knowledge, because knowledge embedded in routines can be transferred more easily than non-codified knowledge (Zander and Kogut, 1995). ${ }^{1}$

Because routines economize managers' time and attention in making decisions, transferring knowledge, and maintaining coordination, the transfer of multinational headquarters' routines to the foreign operation helps to shorten the time that new members of foreign operation need to invest in trial and error experiments in order to know how to interpret and respond to the stimuli that they receive from daily operations, to know about their jobs, and to know how to interact with other members in the organization (Nelson and Winter, 1982; Mahoney 2005). In

\footnotetext{
${ }^{1}$ It should be recognized that routines might contain tacit components as well. Some of the routines may be more difficult to transfer than others (see Szulanski, 1996 for the various difficulties in transferring routines). We thank an anonymous referee for bringing an important distinction between routinization and codification to our attention.
} 
other words, routines accelerate the development of local personnel's ability. In addition, a firm with an established set of routines is also likely to have developed recruiting and training procedures that allow the headquarters to select and modify new members in the foreign operation more effectively.

Routines are recurrent sequences of coordinated actions within the organization. Multinational firms that have greater domestic experience prior to their expansion into the foreign market are likely to have confronted more diverse recurrent challenges and have engaged a substantial amount of trial and error search. Such experiences offer the firm the opportunity of developing (and adapting) a more complete and reliable set of routines, which can serve as a "template" for the to-be-established new routine of the foreign operation (Szulanski and Jensen, 2004), economizing the time and efforts of headquarters' managers in developing local personnel's abilities. Such firms are likely to be able to develop new managerial resources with greater speed than firms that have little home experience, and thus may incur a less serious managerial constraint in the process of subsequent expansion in the foreign market. Therefore, we expect that:

\section{H2: Multinational firms with greater home experience prior to the entry into a foreign market are more likely to achieve growth in successive time periods in the market.}

While a firm's domestic experience allows it to develop a set of routines that can shorten the time that new members of foreign operations need to invest in learning their jobs, these routines alone are not likely to be sufficient because differences in culture, infra-structure, and institutions between home and international markets can create unprecedented managerial challenges that require a firm to adapt its routines and even develop new ones (Luo and Peng, 1999; Lord and Ranft, 2000). A firm with greater international experience prior to its entry into a 
foreign market is likely to have experienced more diverse opportunities that allow it to learn how to deal with local idiosyncratic requirements and how to maintain control and coordination within a network of culturally different and geographically dispersed foreign subsidiaries (Chang and Rosenzweig, 2001; Zahra, Ireland, and Hitt, 2000). As a result, such learning allows the firm to develop a more comprehensive set of routines that can relieve the time and attention of headquarters managers in managing foreign operations and can accelerate the development of local personnel's ability in coordinating within the multinational network.

\section{H3: Multinational firms with greater international experience prior to the entry into a foreign market are more likely to achieve growth in successive time periods in the market.}

As mentioned above, international expansion often requires a multinational firm to develop new routines and/or modify existing ones. Developing new routines or modifying existing routines requires the firm to be able to draw and encode inferences from experience (Levitt and March, 1988). The extent to which a firm can learn may be influenced by the complexity of the local environment in which the firm conducts its business. When a high level

of uncertainty characterizes the entered host market, managers do not necessarily have a clear idea about the linkage between organizational action and environmental responses (Levinthal and March, 1981). The difficulty in interpreting the results of managerial decisions will, in turn, make it difficult for the managers to draw inferences and lessons from experience in the local market.

Therefore, in a highly uncertain local market, managers of the foreign operation will need to give more time and efforts in figuring out the ways things work in the particular environment and hence may have little time left for mentoring new personnel. In addition, the "causal ambiguity" in the experience due to the high level of uncertainty in the local market is 
likely to further hamper the learning that takes place among these new personnel (Lippman and Rumelt, 1982; Szulanski, 1996). Because uncertainty can slow down the development of new managerial resources in the foreign operation, multinational firms are likely to be subject to a more serious managerial constraint in local markets that are characterized by a high level of uncertainty.

\section{H4: Multinational firms are less likely to achieve high growth rates in successive time periods in a foreign market that is characterized by a high level of uncertainty.}

We have now developed four hypotheses concerning how subsidiary characteristic (i.e., expatriates utilization), parent characteristics (i.e., prior domestic and international experience), and local market characteristic (i.e., the level of uncertainty), can influence the dynamic supply of managerial resources in foreign operations, and in turn can have an effect on the potential Penrose effect that the firm may encounter in expanding in the local market. We next empirically test these hypotheses and report the results.

\section{Methodology}

The initial population consists of all Japanese manufacturing affiliates in United States, which meet the following two criteria: (1) the Japanese parent firm is listed in the first or second section of the Japanese Stock Exchange, (2) the parent firm entered the particular U.S. industries between 1978 and 1990. Japanese investments are appropriate for examining growth because it is generally believed that Japanese companies pursue long-term growth rather than short-term profitability (Abegglen and Stalk, 1985; Odagiri, 1992). We studied Japanese investments in the U.S. market because the United States was the leading destination of foreign direct investment outflow from Japanese firms over the study time period. We excluded non- majority-owned investments because Japanese firms have less control over these investments and thus the growth 
orientation of these investments may be different. The sample is compiled from annual issues of Japan's Expanding Manufacturing Presence in the United States: A profile and Kaigai Shinshutsu Kigyo Soran. The two data sources also provide information on the year of establishment, mode of entry, the number of expatriates and employees, and the equity percentage of individual affiliates.

The level of analysis is at the line of business. We studied the growth of a firm empirically at the line of business instead of the whole corporation because the nature of industries may vary. Since many multinational firms entered multiple foreign industries, the growth of a firm as a whole in a foreign country would be too broad to unveil the relationship between managerial constraints and growth. We aggregated a Japanese parent firm's affiliates within a four-digit SIC industry and define it as an 'investment.' Our initial sample consists of 324 investments, representing 207 Japanese firms in 165 four-digit SIC industries. Lack of parent, industry, and affiliate data reduced our sample size to 118 investments, representing 92 Japanese firms in 79 industries. $^{2}$

In the current research paper we examine under what conditions Japanese firms that grow fast in one time period incur a slower subsequent growth rate in the entered U.S. industries. The growth rate is measured as the percentage of the change of firm size over a three-year period. We measure firm size by employment within a foreign industry because (1) the theoretical interest of the current paper concerns the managerial constraint on the rate of growth and the majority of managerial tasks will be related to the management of employees; (2) employment as a size measure is rightfully the common practice in empirical research studies investigating managerial

\footnotetext{
${ }^{2}$ A t-test showed no statistically significant differences in the sizes and the ages of the parent firms in the final sample when compared to those not included in the sample suggesting that sample selection bias is not a problem in this empirical study.
} 
constraints to firms; and (3) other firm size measures in this international business context are not readily available to researchers. ${ }^{3}$

Since firm-level growth is substantially influenced by its age (Hay and Morris, 1991), examining the impact of managerial constraint on firm growth would be more meaningful if the growth rates of firms at the same stages are compared. Thus, for each Japanese investor in a given U.S. market, we analyzed the growth of the first starting three-year time period and the growth of the following three-year time period. Specifically, the dependent variable is the percentage change in a Japanese firm's total employment ${ }^{4}$ in a given U.S. industry between the fourth and the seventh years after entry (GROWTH). The key explanatory variable (PREGROW) is the percentage change of the employment in the preceding period (i.e., between the first and the fourth years).

The hypotheses were tested using regression models, which are comparable to previous empirical studies (Weinzimmer, Nystrom, and Freeman, 1998) that studied firm growth. To examine our hypotheses that predict the conditions under which firms incur a higher/lower level of managerial constraints, we entered the interaction terms between the preceding growth rate and the variables of interests in the regression.

The variables of interests that are multiplied by the preceding growth rates include: (1) EXPAT, the ratio of expatriate employees to total employees in the Japanese firm's first affiliate in the given U.S. industry. We used the ratio instead of the absolute number of expatriates in order to adjust expatriate utilization for the size of the affiliate; (2) HomeExp, the proxy for a

\footnotetext{
${ }^{3}$ Our data source, Kaigai Shinshutsu Kigyo Soran, provides sales data to a very limited number of affiliates. For the 46 investments in our sample that we could get access to both sales and employment data to estimate growth rates, we found that the growth in employment and growth in sales are significantly correlated at the 0.005 -level $(\mathrm{r}=42.55)$.

${ }^{4}$ The employment of joint ventures was prorated by the equity share of the parents.
} 
firm's home experience. It is measured by the number of years between the firm's foundation and the establishment of its first operation in the U.S. industry; (3) InternationalExp, the proxy for a firm's international experience. It was measured by the number of years between the firm's establishment of its first overseas operation and its first operation in the U.S. industry. The data for the first three variables were all taken from Kaigai Shinshutsu Kigyo Soran., and (4) UNCERTAINTY, a proxy for the level of uncertainty in the entered U.S. market. It is constructed by using Levy's (1985) measure. Specifically, we regress the logarithm of the real shipments of the given 4-digit SIC United States industry from 1977 to 2000 on $t$ where $t$ ranges from 1 to 24 (source: United States Bureau of Economic Analysis). The variance of the error term is used as the measure for uncertainty.

We included several control variables that may influence the growth of a firm in a foreign industry: (1) ACQ, a dummy equal to one if a firm follows an acquisition strategy to enter into a particular 4-digit industry during the first three years. If a firm has more than one entry in an industry, we classify a firm's entry as an acquisition strategy when the percentage of acquisition in a firm's entries is greater than 50 percent, and zero otherwise. Acquisition may accelerate a firm's entry into the U.S. market; (2) JV, a dummy equal to one if the Japanese firm entered into the U.S, industry via a majority-owned joint venture. Managing joint ventures may require a different set of skills that influence the managerial constraint of a firm. The data of ACQ and JV were both take from Japan's Expanding Manufacturing Presence in the United States: A profile; (3) DIVER, a dummy equal to 1 if the four-digit SIC products made by the affiliate do not match those made by the parent at the time of the focal expansion. If the U.S. affiliate does not produce the same products as those of the Japanese parent, it is likely that the U.S. investment is a diversification for the parent firm. In that case, the affiliate may experience 
slower growth because the parent lacks operating expertise in the diversified business; (4) FRD, a proxy for a firm's technological competencies. It is the R\&D intensity of the Japanese parent firm (the ratio of R\&D expenditure to sales). Firms that invest more in $R \& D$ may be able to create greater technological capabilities that facilitate growth; (5) FADV, a proxy for a firm's marketing competencies. It is the advertising intensity of the Japanese parent firm (the ratio of advertising expenditures to sales). Firms that invest more in advertising may be able to create greater marketing capabilities that enhance growth; (6) LIQUID, a proxy for a firm's financial support to international expansion. This proxy is the ratio of the parent firm's working capital to sale. Lack of financial support may hamper a firm's expansion in the foreign market. The three parent-level control variables, FRD, FADV, and LIQUID were all measured in the beginning of the observation period (i.e., the end of the third year after entry), and were taken from the Nikkei Database; (7) INDGROW, the average annual growth rate of total employment of a four-digit SIC US industry over the observation time period. Firms that enter fast growing industries are likely to grow faster; and (8) SIZE, was measured by the (logarithm) employment size of subsidiary in the beginning of the observation period (i.e., at the end of the third year after entry). It has often been found that a firm's rate of growth is negatively associated with its size (Jovanovic, 1982; Sutton, 1997).

\section{Results}

We converted HomeExp, InternationalExp, and SIZE to logarithmic form in order to remove the skewness in the variables. We also centered the variables used to construct interaction terms in the estimation to reduce the multicollinearity problem that is typically associated with moderated regression (Aiken \& West, 1991). Table 1 provides descriptive statistics and a correlation matrix, in which means and standard deviations based on raw data are 
presented to simplify interpretation. Although a number of variables are correlated with other variables at the 0.05 level, the largest variance inflation factor (VIF) in the model (3.24) is far below 10 , and the mean VIF value (1.80) is close to 1 , suggesting that multicollinearity does not threaten the validity of our coefficient estimate (Neter, Kutner, Nachtsheim and Wasserman, 1999).

Place Tables 1 and 2 about here

Table 2 presents the empirical results. The dependent variable is the percentage change in a Japanese firm's total employment in a given U.S. industry between the fourth and the seventh years after entry. The key explanatory variable (PREGROW) is the percentage change of the employment in the preceding time period (i.e., between first and the fourth years). Our hypotheses predict the conditions under which a Japanese firm is more or less likely to achieve growth in a U.S. industry for two successive time periods. We entered the interaction terms between PREGROW and the four variables of interest (EXPAT, HomeExp, InternationalExp, and UNCERTAINTY) in turn in the model. A positive (negative) coefficient of the interaction term suggests that in the particular condition the Japanese firms are more (less) likely to achieve growth for the two successive time periods in the U.S. industries.

Models 1-5 report the regression results. As shown in Model 1, the coefficient of the interaction term between EXPAT and PREGROW is positive and statistically significant at the 0.05-level, providing empirical support for hypothesis 1 . The empirical result in Model 2 indicates that the coefficient of HomeExp*PREGROW is positive and statistically significant at the 0.005-level, providing empirical support for hypothesis 2 . The coefficient of Intexp*PREGROW is positive but not statistically significant, as shown in Model 3. Therefore, 
hypothesis 3 is not supported. One potential reason is that firms with greater international experience have had spread into many different international markets and the increased complexity in international management may have raised the demand for services from the managers (Hitt, Hoskisson, and Kim, 1997). In other words, while having international presence may facilitate the dynamic supply of managerial resources, it may have also put a greater pressure for the demand of the managerial services.

The empirical result in Model 4 indicates that the coefficient of UNCERTAINTY*PREGROW is negative and statistically significant at the 0.5 -level, providing empirical support for hypothesis 4. Lastly, we estimate the effects of all four of the interaction terms in Model 5. As expected, the combined effect of the interaction terms is statistically significant. The directions and the statistical significance levels of interaction terms in Model 5 are consistent with those in Models $1-4$.

Although the statistical significance of interaction terms in the moderated regression models provide empirical support for Hypotheses 1, 2, and 4, the examination of interaction plots presents further insights into the specific moderating effects. Following the procedures recommended by Aiken and West (1991), we illustrate in Figures 1-3 the simple slopes of the interaction terms. Figure 1 indicates a positive relationship between previous growth and current growth for entrants that sent a greater number of expatriates to the foreign operation, and a negative relationship for entrants that sent fewer expatriates to the foreign operation. Figure 2 reveals that the positive sign of the interaction term between PREGROW and HomeExp is the product of a steeper (more positive) slope for the relationship between current growth and previous growth for entrants with greater home experience, and a less steep slope for those with little home experience. Figure 3 presents a negative relationship between current growth and 
previous growth for entrants in local markets characterized by a high level of uncertainty, and a positive relationship for entrants in local markets that are characterized by a low level of uncertainty. On the whole, such empirical results are consistent with our hypotheses: multinational firms that are able to accelerate the development of new managerial resources in the foreign operation are less vulnerable to the Penrose Effect and can achieve growth in successive time periods. On the other hand, in situations under which the development of new managerial resources in the foreign operation takes longer time, a fast-growing firm is not likely to adjust its managerial resources in a timely manner, and thus is likely to slow down in the subsequent expansion.

Turning to our control variables, consistent with the findings of many empirical studies that investigate the relationship between firm size and growth (Sutton, 1997), our empirical result indicates that a Japanese firm's size (SIZE) in the U.S. market was negatively associated with its growth rate in the market. Our results also show that Japanese firms that made diversified investment (DIVER) in the U.S. have grown slower. All other control variables are generally insignificant. ${ }^{5}$

${ }^{5}$ Did on average Japanese firms achieve growth in consecutive periods in the US market? Shen (1970) suggests that if not for managerial constraints, growth rates of successive periods would be positively correlated because larger firms enjoy increasing returns to scale for labor (p.706) and can benefit more from technological change (p.707 footnote) and therefore can grow faster. Tan and Mahoney (2005) suggest that it might be possible for firms to achieve growth in successive periods in foreign markets because the need for close coordination between overseas operations may be lower than between domestic ones. Our empirical results indicate that the correlation coefficient between PREGROW and GROWTH is not statistically significant at the 0.05 level in Table 1. While the coefficient of PREGROW is positive across columns in Table 2, the impact of PREGROW on growth is captured by the coefficient of PREGROW and the coefficients of interaction terms between PREGROW and the variables of interests (including EXPAT, HomeExp, InternationalExp, and UNCERTAINTY), is more clearly presented in Figures 1-3. As shown in Figures 1-3, Japanese firms achieved growth in consecutive periods (i.e., the positive slope of the relationship between PREGROW and GROWTH) when they sent more expatriates, had more domestic experience prior to entry, and had entered less uncertain markets (i.e., when they were more capable of developing new managerial resources). 


\section{Discussion and Conclusions}

This empirical paper explores the conditions under which a firm is more/less likely to incur the Penrose Effect when expanding in a foreign market. We have argued that firms that can accelerate the development of new managerial resources in their foreign operations are more capable to adjust their managerial resources timely in the process of expansion, and thus are less vulnerable to the managerial constraint on the rate of growth. On the other hand, factors that impede the development of new managerial resources in foreign operations will prevent multinational firms from growing fast in consecutive time periods.

Based on a longitudinal sample of Japanese manufacturing entries in the United States, our empirical results indicate that Japanese firms were more likely to achieve growth in consecutive time periods when these firms sent more expatriates to the foreign operation at the time of entry. The development of new managerial resources in foreign operations requires the managerial services of experienced headquarters managers. A higher ratio of expatriates in the foreign operation at the initial stage allow the newly-recruited local personnel in the foreign operation to gain more time and attention from the experienced headquarters managers, and thus can be helpful in the development of new managerial resources in the foreign operation. Such an empirical finding suggests that expatriation may be viewed as an investment in developing human capital (Becker, 1964) in foreign operations. Previous research literature has argued that expatriation is a primary way for a firm to develop its own managers, in the sense that expatriates gain local knowledge and broaden their visions from their international experience (e.g., Edstrom and Galbraith, 1977). The empirical finding of our research paper suggests that expatriation at the initial stage of international expansion may also be helpful in developing the abilities of local personnel. 
Our empirical results also indicate that Japanese firms were more likely to achieve growth in successive time periods (and hence were less vulnerable to the Penrose effect) in the given U.S. market when they had greater home experience prior to their entry into the given market. Greater experience at home allows firms to develop a set of more complete and reliable routines that can be more readily transferred to the foreign operation, and thus can accelerate the development of new managerial resources in the foreign operation.

The empirical results also indicate that Japanese firms were less likely to achieve growth in consecutive time periods when the entered local markets had a high level of uncertainty. A high level of uncertainty may slow down the development of new managerial resources in the foreign operation because the "causal ambiguity" in the experiences is likely to hamper the learning of managers in the foreign operation. Thus, multinational firms are less likely to be able to adjust their managerial resources timely and may incur a more serious managerial constraint in the process of expansion.

This empirical paper makes the following contributions to the research literature. First, past empirical studies on the Penrose effect have generally focused on whether the Penrose effect exists. Our empirical study goes beyond that focus and explores the "when" question - under what conditions are the Penrose Effect more likely to exist? In particular, our empirical study extends the research literature by linking factors that influence the dynamic supply of managerial resources to the Penrose effect. Second, empirical work on the Penrose Effect has been scarce. Our empirical paper contributes to the research literature by providing empirical evidence for the Penrose Effect. All of the hypotheses developed in our empirical paper have not yet been systematically probed in the research literature. Third, while empirical evidence for the Penrose Effect in domestic contexts is already limited, empirical evidence for the Penrose Effect in 
international contexts is even scarcer. One of the reasons may be that it is difficult to gain access to longitudinal international data that are required for examining growth. We contribute to the understanding of the Penrose Effect in international contexts by uncovering and testing some parent-, subsidiary-, and local market- level factors that may influence the Penrose Effect that a firm can encounter when expanding in a foreign market. Our empirical findings show that factors that facilitate the development of new managerial resources in foreign operations have allowed Japanese firms to be less vulnerable to managerial constraints as these firms expanded in the U.S. market, and that factors that impede the development of new managerial resources have also prevented firms from achieving growth in consecutive time periods.

While this empirical research study advances our understanding of the Penrose Effect in international expansion, there are several directions that seem promising to advance this line of research. For instance, the empirical findings in the current research paper are based solely on Japanese firms' manufacturing entries into the United States. Future research could provide insight into the generalizability of the current paper's empirical findings by using samples from other home and/or host countries. In addition, longitudinal international data are notoriously difficult to gain access to for the purpose of scholarly research. Perhaps due to this reason, empirical evidence for the Penrose Effect in an international context is rather limited. The limitation of international data has also constrained our ability to test empirically more fine-grained hypotheses concerning the supply of managerial resources. Future research could collect more detailed international data, and develop and test more fine-grained hypotheses concerning the Penrose Effect.

In addition, our empirical finding indicates that Japanese firms that sent a greater number of expatriates to U.S. operations at the time of entry were more likely to achieve 
successive growth. Future research studies could further explore the impact of the characteristics of expatriates on the development of local personnel in the foreign operation. For example, it would be interesting to examine how the industry and firm experiences of expatriates, and the functional composition of expatriates, may influence the speed with which the new foreign operation develops managerial resources. Finally, our empirical results suggest that the extent to which a firm incurs the Penrose Effect when expanding abroad can be influenced by its own firm- and subsidiary- level characteristics and the characteristics of the local market that it chooses to enter. Future research could extend this idea and explore other factors that might moderate the level of the managerial constraints that a firm may face in the process of expansion. 
Table 1 Correlations, Means, and Standard Deviations ${ }^{6}$

\begin{tabular}{|c|c|c|c|c|c|c|c|c|c|c|c|c|c|c|c|}
\hline Variable & Mean & s.d. & 1 & 2 & 3 & 4 & 5 & 6 & 7 & 8 & 9 & 10 & 11 & 12 & 13 \\
\hline 1. GROWTH & 0.47 & 1.00 & & & & & & & & & & & & & \\
\hline 3. LIQUID & 0.55 & 0.37 & -0.05 & 0.21 & & & & & & & & & & & \\
\hline 4. FRD & 1.71 & 1.77 & 0.06 & 0.21 & 0.22 & & & & & & & & & & \\
\hline 6. SIZE & 310.9 & 738.9 & -0.09 & 0.13 & 0.14 & 0.02 & -0.01 & & & & & & & & \\
\hline 7. ACQ & 0.36 & 0.48 & -0.13 & -0.07 & 0.07 & -0.05 & -0.05 & 0.20 & & & & & & & \\
\hline 8. JV & 0.34 & 0.48 & 0.10 & 0.11 & -0.17 & 0.03 & -0.14 & 0.12 & -0.20 & & & & & & \\
\hline 9. DIVER & 0.16 & 0.37 & -0.14 & -0.05 & -0.04 & -0.03 & -0.09 & -0.08 & 0.20 & 0.03 & & & & & \\
\hline 13. InternationalExp & 15.87 & 8.98 & 0.01 & -0.06 & 0.06 & 0.22 & 0.11 & -0.01 & 0.07 & -0.15 & 0.12 & -0.09 & -0.10 & 0.30 & \\
\hline 14. UNCERTAINTY & 0.01 & 0.01 & -0.04 & -0.04 & 0.00 & -0.05 & -0.09 & 0.01 & 0.05 & 0.09 & 0.17 & 0.50 & 0.01 & 0.12 & 0.04 \\
\hline
\end{tabular}

${ }^{6} \mathrm{~N}=118$; correlations greater than 0.18 or smaller than -0.18 are significant at the 0.05 level. 


\section{Table 2 Regression Results ${ }^{7}$}

\begin{tabular}{|c|c|c|c|c|c|c|c|c|c|c|c|c|c|c|c|}
\hline \multirow{2}{*}{$\begin{array}{l}\text { Variable } \\
\text { PREGROW*EXPAT }\end{array}$} & \multicolumn{3}{|c|}{ (1) } & \multicolumn{3}{|c|}{ (2) } & \multicolumn{3}{|c|}{ (3) } & \multicolumn{3}{|c|}{ (4) } & \multicolumn{3}{|c|}{ (5) } \\
\hline & 0.653 & $(0.312)$ & $*$ & & & & & & & & & & 0.503 & $(0.320)$ & $\dagger$ \\
\hline PREGROW*HomeExp & & & & 0.120 & $(0.045)$ & $* * *$ & & & & & & & 0.094 & $(0.048)$ & $*$ \\
\hline PREGROW*InternationalExp & & & & & & & 0.048 & $(0.041)$ & & & & & -0.007 & $(0.044)$ & \\
\hline PREGROW*UNCERTAINTY & & & & & & & & & & -12.946 & $(6.810)$ & * & -13.045 & $(7.074)$ & $*$ \\
\hline \multicolumn{16}{|l|}{ Control Variable: } \\
\hline CONSTANT & 1.721 & $(0.440)$ & $* * *$ & 2.193 & $(0.473)$ & $* * *$ & 1.813 & $(0.458)$ & $* * *$ & 1.461 & $(0.459)$ & $* * *$ & 1.849 & $(0.500)$ & $* * *$ \\
\hline PREGROW & 0.038 & $(0.025)$ & $\dagger$ & 0.102 & $(0.026)$ & $* * *$ & 0.065 & $(0.023)$ & $* * *$ & 0.057 & $(0.023)$ & $* *$ & 0.067 & $(0.032)$ & $*$ \\
\hline LIQUID & -0.215 & $(0.262)$ & & -0.533 & $(0.285)$ & & -0.307 & $(0.278)$ & & 0.122 & $(0.317)$ & & -0.113 & $(0.358)$ & \\
\hline FRD & 0.001 & $(0.054)$ & & -0.012 & $(0.054)$ & & -0.004 & $(0.056)$ & & -0.021 & $(0.057)$ & & -0.044 & $(0.056)$ & \\
\hline FADV & 0.023 & $(0.102)$ & & 0.069 & $(0.097)$ & & 0.060 & $(0.101)$ & & 0.064 & $(0.099)$ & & 0.012 & $(0.101)$ & \\
\hline SIZE & -0.237 & $(0.079)$ & $* * *$ & -0.282 & $(0.080)$ & $* * *$ & -0.237 & $(0.080)$ & $* * *$ & -0.207 & $(0.081)$ & $* * *$ & -0.245 & $(0.081)$ & $* * *$ \\
\hline $\mathrm{ACQ}$ & -0.260 & $(0.221)$ & & -0.112 & $(0.207)$ & & -0.146 & $(0.214)$ & & -0.186 & $(0.214)$ & & -0.287 & $(0.220)$ & $\dagger$ \\
\hline JV & 0.116 & $(0.204)$ & & 0.081 & $(0.200)$ & & 0.076 & $(0.206)$ & & 0.096 & $(0.204)$ & & 0.142 & $(0.199)$ & \\
\hline DIVER & -0.372 & $(0.254)$ & $\dagger$ & -0.483 & $(0.251)$ & $*$ & -0.456 & $(0.258)$ & $*$ & -0.458 & $(0.255)$ & $*$ & -0.457 & $(0.251)$ & $*$ \\
\hline INDGROW & 0.381 & $(1.838)$ & & -0.917 & $(1.859)$ & & -0.018 & $(1.870)$ & & 0.049 & $(1.844)$ & & -0.617 & $(1.850)$ & \\
\hline EXPAT & -1.153 & $(0.715)$ & $\dagger$ & -1.098 & $(0.700)$ & $\dagger$ & -0.906 & $(0.715)$ & & -0.988 & $(0.709)$ & $\dagger$ & -1.347 & $(0.701)$ & $*$ \\
\hline HomeExp & 0.648 & $(0.260)$ & $* *$ & 0.586 & $(0.258)$ & $*$ & 0.608 & $(0.267)$ & $*$ & 0.677 & $(0.261)$ & $* *$ & 0.619 & $(0.259)$ & $* *$ \\
\hline InternationalExp & -0.036 & $(0.098)$ & & -0.033 & $(0.096)$ & & 0.020 & $(0.109)$ & & -0.030 & $(0.098)$ & & -0.038 & $(0.107)$ & \\
\hline UNCERTAINTY & -6.448 & $(10.995)$ & & -1.629 & (10.979) & & -5.270 & (11.169) & & -25.271 & (14.989) & $*$ & -22.473 & (15.314) & $\dagger$ \\
\hline $\mathrm{N}$ & & 118 & & & 118 & & & 118 & & & 118 & & & 118 & \\
\hline $\mathrm{F}$ & & 1.94 & & & 2.18 & & & 1.68 & & & 1.88 & & & 2.17 & \\
\hline Prob $>$ F & & 0.03 & & & 0.01 & & & 0.07 & & & 0.04 & & & 0.01 & \\
\hline R-squared & & 0.21 & & & 0.23 & & & 0.19 & & & 0.20 & & & 0.27 & \\
\hline Adj R-squared & & 0.10 & & & 0.12 & & & 0.08 & & & 0.10 & & & 0.15 & \\
\hline
\end{tabular}

${ }^{7}$ Cell entries are unstandardized coefficient estimates. Numbers in parentheses are standard errors. 
$\dagger \mathrm{p}<0.1 * \mathrm{p}<0.05 * * \mathrm{p}<0.01 * * * \mathrm{p}<0.005$ (One-tailed test) 


\section{Figure 1}

Plot of Hypothesis 1: The effect of the ratio of expatriates on the relationship between firm growth and previous firm growth

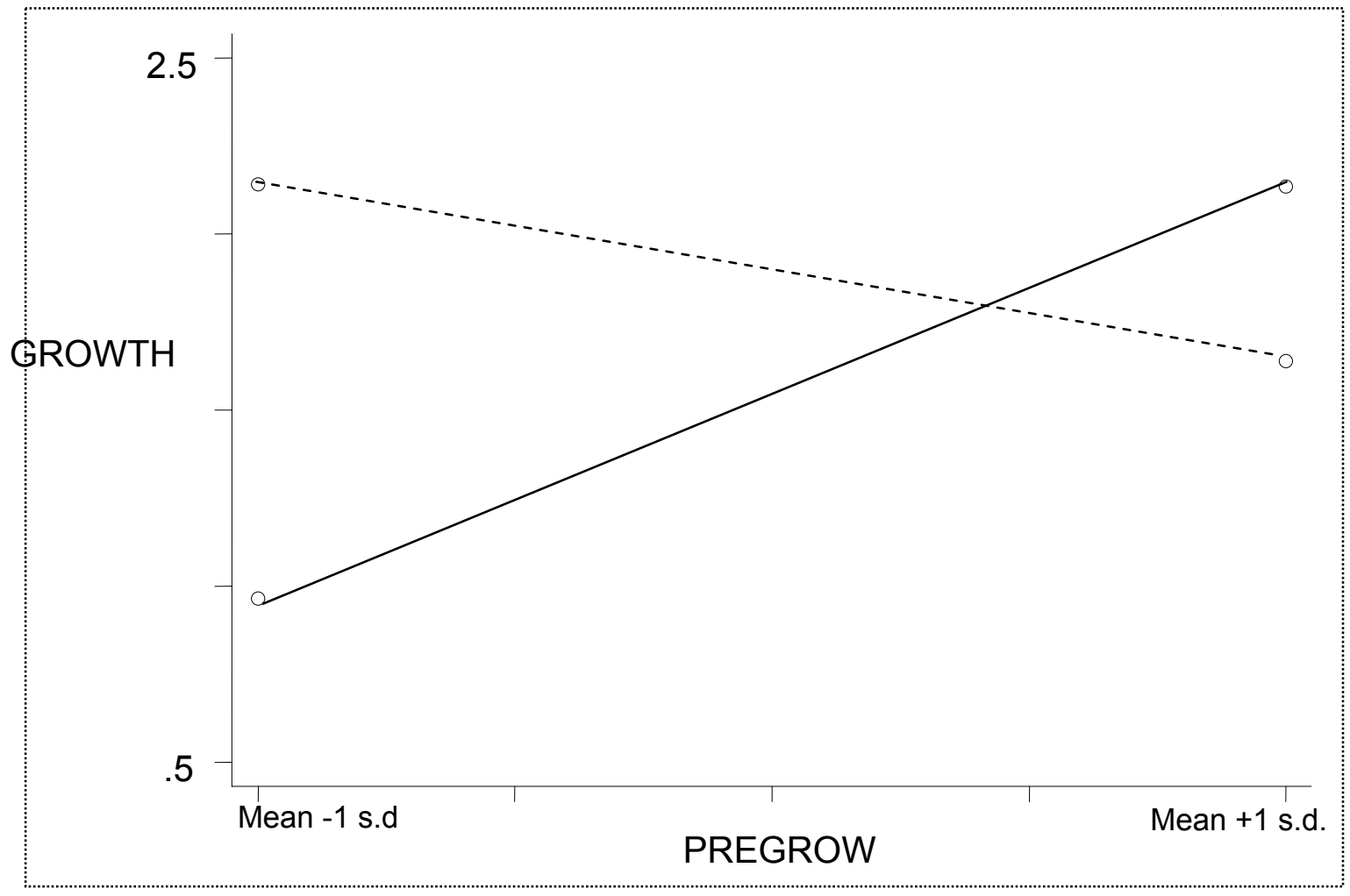

High ratio of expatriates

---------- Low ratio of expatriates 
Figure 2

Plot of Hypothesis 2: The effect of prior home experience on the relationship between firm growth and previous firm growth

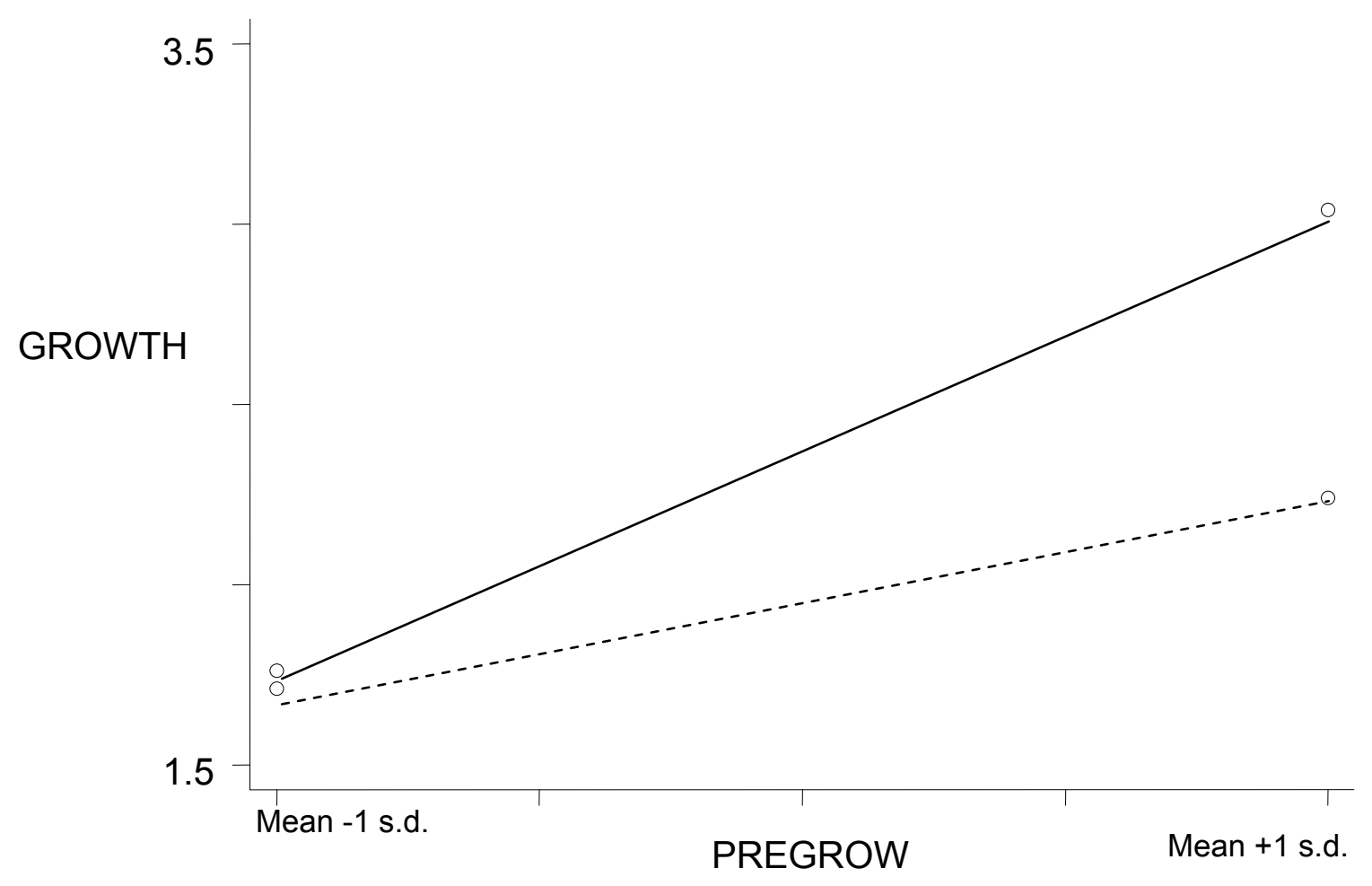

Great prior home experience

Little prior home experience 


\section{Figure 3}

Plot of Hypothesis 3: The effect of industry uncertainty on the relationship between firm growth and previous firm growth

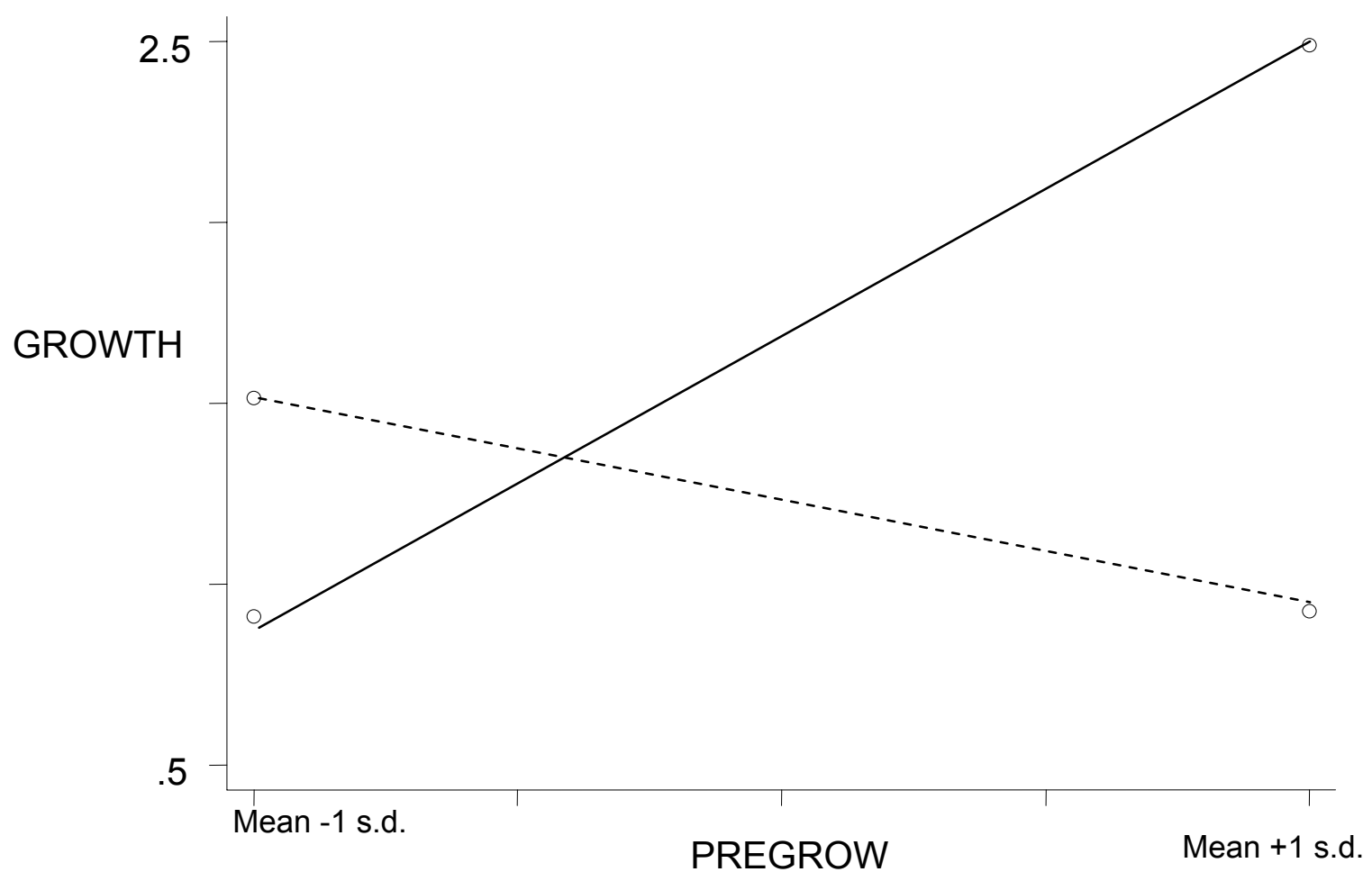

High level of market uncertainty

---------- Low level of market uncertainty 


\section{References}

Abegglen, J. C., and G. Stalk Jr. (1985). Kaisha, The Japanese Corporation. NY: Basic Books.

Aiken, L.S. and S. G. West (1991). Multiple Regression: Testing and Interpreting Interactions. London: Sage.

Barney, J. B. (1986). Strategic factor markets: Expectations, luck and business strategy. Management Science, 32: 1231-1241.

Becker, G. S. (1964). Human Capital. New York: National Bureau of Economic Research.

Beechler S, and J. Z.Yang (1994). The transfer of Japanese-style management to American subsidiaries: contingencies, constraints, and competencies. Journal of International Business Studies, third quarter: 467-491.

Chang, S. J. (1995). International expansion strategy of Japanese firms: capabilities building through sequential entry. Academy of Management Journal, 38(2): 383-407.

Chang, S. J. and Rosenzweig, P. (2001). The choice of entry mode in sequential foreign direct investment. Strategic Management Journal, 22(8): 747-776.

Cyert, R. M. and J. G. March (1963). A Behavioral Theory of the Firm. Englewood, Cliffs, NJ: Prentice-Hall.

Dierickx, I. and K. Cool (1989). Asset stock accumulation and sustainability of competitive advantage. Management Science, 35(12): 1504-1511.

Edström, A. and J. R. Galbraith (1977). Transfer of managers as a coordination and control strategy in multinational corporations. Administrative Science Quarterly, 22: 248-63.

Eisenhardt, K. M. (1985). Control: Organizational and economic approaches. Management Science, 31:134-49.

Gander, J. P. (1991). Managerial intensity, firm size and growth. Managerial and Decision Economics, 12: 261-266.

Hay, D. A., and D. J. Morris (1991). Industrial Economics and Organization: Theory and Evidence. NY: Oxford University Press.

Hennart, J-F. (1991). Control in multinational firms: the role of price and hierarchy. Management International Review, 31: 71-96.

Hitt, M. A., Hoskisson, R.E. and Kim, H. 1997. International Diversification: Effects on Innovation and Firm Performance in Product-Diversified Firms. Academy of Management Journal, 40 (4): 767-798. 
Huber, G. P. (1991). Organizational learning: The contributing processes and the literatures. Organization Science, 2(1): 88-115.

Japan Economic Institute of America. Japan's Expanding Manufacturing Presence in the United States: A profile. Washington, D.C.: Japan Economic Institute of America, Various years.

Jovanovic, B. (1982). Selection and evolution of industry. Econometrica, 50(3): 649-670.

Kor Y. Y. and J. T. Mahoney (2000). Penrose's resource-based approach: The process and product of research creativity. Journal of Management Studies, 37 (1): 109-139.

Kuemmerle W. (1997). Building effective R\&D capabilities abroad. Harvard Business Review 75(2): 61-70.

Levinthal, D. and J. G. March (1981). A model of adaptive organizational search. Journal of Economic Behavior and Organization, 2: 307-333.

Levitt, B. and J. G. March (1988). Organizational learning. Annual Review of Sociology, 14: 319-340.

Levy, D. T. (1985). The transaction cost approach to vertical integration: An empirical investigation. Review of Economics and Statistics, 67: 438-445.

Lippman, S. A. and R. P. Rumelt (1982). Uncertain imitability: An analysis of interfirm differences in efficiency under competition. Bell Journal of Economics, 13: 418-38.

Lord, M. D. and A. L. Ranft (2000). Organizational learning about new international markets: Exploring the internal transfer of local market knowledge. Journal of International Business Studies, 31(4): 573-589.

Lucas R. E. (1967). Adjustment costs and the theory of supply. Journal of Political Economy, 75: 321-343.

Luo Y. and M. W. Peng. (1999). Learning to compete in a transition economy: Experience, environment, and performance. Journal of International Business Studies, 30(2): 269-96.

Mahoney, J. T. (1995). The management of resources and the resource of management. Journal of Business Research, 33: 91-101.

Mahoney, J. T. (2005). Economic Foundations of Strategy. Thousand Oaks, CA: Sage Publications.

March, J. G. and H. A. Simon (1958). Organization. New York, NY: John Wiley \& Sons.

Marris, R. (1963). A model of the 'managerial' enterprise. Quarterly Journal of Economics, 88: 181-193. 
Marris, R. (1964). The Economic Theory of 'Managerial Capitalism.' New York, NY: The Free Press of Glencoe, a division of the MacMillan Company.

Mortensen D.T. (1973). Generalized costs of adjustment and dynamic factor demand theory. Econometrica, 41: 657-665.

Nelson R.R, and S. G. Winter (1982). An Evolutionary Theory of Economic Change. Belnap/Harvard University Press: Cambridge, MA.

Neter J, M. H. Kutner, C. J. Nachtsheim, and W. Wasserrman (1999). Applied Linear Statistical Models. Fourth edition. New York: McGraw-Hill.

Odagiri, H. (1992). Growth Through Competition, Competition Through Growt $\underline{\text {. }}$ NY: Oxford University Press.

O'Donnell, S. W. (2000). Managing foreign subsidiaries: Agents of headquarters, or an independent network? Strategic Management Journal, 21: 525-48.

Orser, B. J., S. Hogarth-Scott, and A. L. Riding (2000). Performance, firm size, and management problem solving. Journal of Small Business Management, October: 42-58.

Ouchi W. (1979). A conceptual framework for the design of organizational control mechanisms. Management Science, 25(9): 833-849.

Penrose, E. (1959). The Theory of the Growth of the Firm. New York: Oxford University Press.

Pitelis, C. (2002). The Growth of the Firm: The Legacy of Edith Penrose. New York, NY: Oxford University Press.

Polanyi, M. (1962). Personal Knowledge. Chicago, IL: University of Chicago Press.

Rubin P. H. (1973). The expansion of firms. Journal of Political Economy, 81: 936-949.

Shane, S. A. (1996). Hybrid organizational arrangements and their implications for firm growth and survival: A study of new franchisors. Academy of Management Journal, 39(1): 216-234.

Shen, T. Y. (1970). Economies of scale, Penrose-effect, growth of plants and their size distribution. Journal of Political Economy, 78(4): 702-716.

Slater M. (1980). The managerial limitations to a firm's rate of growth. Economic Journal, 90: 520-528.

Subramaniam, M. and N. Venkatraman (2001). Determinants of Transnational New Product Development Capability: Testing the Influence of Transferring and Deploying Tacit Overseas Knowledge. Strategic Management Journal, 22: 359-78. 
Sutton, J. (1997). Gibrat's legacy. Journal of Economic Literature. 35: 40-59.

Szulanski, G. (1996). Exploring internal stickness: Impediments to the transfer of best practice within the firm. Strategic Management Journal, 17(winter special): 27-43.

Szulanski, G. and R. J. Jensen. (2004). Overcoming stickiness: An empirical investigation of the role of the template in the replication of organizational routines. Managerial and Decision Economics, 25: 347-363.

Tan, D. (2003). The limits to the growth of multinational firms in a foreign market. Managerial and Decision Economics, 24: 569-582.

Tan, D. and J. T. Mahoney (2005). Examining the Penrose Effect in an international business context: The dynamics of Japanese firm growth in U.S. industries. Managerial and Decision Economics, 26: 113-127.

Teece, D.J., G. Pisano, and A. Shuen. (1997). Dynamic capabilities and strategic management. Strategic Management Journal, 18(7): 509-533.

Thompson, R. S. (1994). The franchise life cycle and the Penrose effect. Journal of Economic Behavior and Organization, 24: 207-218.

Toyo Keizai. Kaigai Shinshutsu Kigyo Soran. Various years. Toyo Keizai: Tokyo.

Treadway A. B. (1970). Adjustment costs and variable inputs in the theory of the competitive firm. Journal of Economic Theory, 2: 329-347.

Verbeke, A. (2003). The evolutionary view of the MNE and the future of internalization theory. Journal of International Business Studies, 34 (6): 498-504.

Weinzimmer, L. G., P. C. Nystrom, and S. J. Freeman (1998). Measuring organizational growth: Issues, consequences and guidelines. Journal of Management, 24 (2), 235-262.

Zahra, S.A., Ireland, R.D. \& Hitt, M.A. (2000) 'International expansion by new venture firms: International diversify, mode of market entry, technological learning, and performance', Academy of Management Journal 43(5): 925-950.

Zander, U. and B. Kogut (1995). Knowledge and the speed of transfer and imitation of organizational capabilities: An empirical test. Organization Science, 6 (1): 76-92. 